\title{
朝鮮平安南道殷山地方の花崗閃綠岩體の構造について
}

(岩石の構浩ならびに生成機構に關する研究 II)

\author{
鈴机淑尘
}

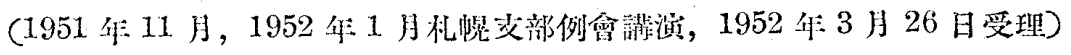

1. 緒 言

2. 程石》商㧋

3. 岩石以性留

A. 一標本队方成分變化

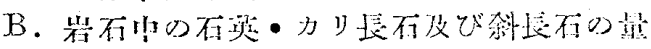

C. 岩石山有色释物量

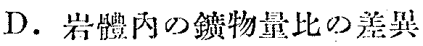

4. 梌不四心斜展石成分

5. 綡括
1. 硣

言

この故管出北海道大學の石 川俊头敉授が, 1941 年に朝鮮

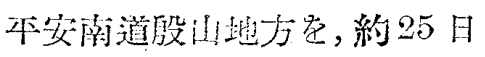

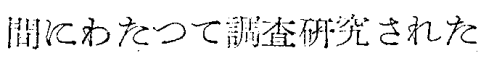
際探集されを絇５00 㑑の標

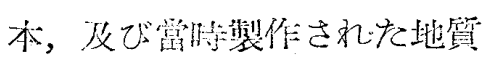
圖等老基江して，同地方の深

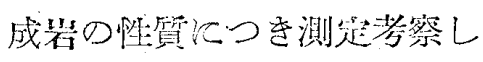

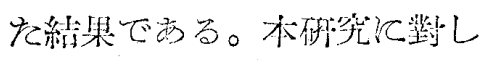

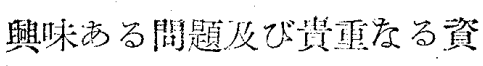
料空與之方衣，かつ終始御指

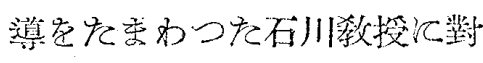
し深く感謝する炏第で西る。

\section{2. 岩石の産狀}

本地域结北緯 39 度 20 分, 東經 126 度附近江的り，壮壤 の北西方約 $50 \mathrm{~km}$ 亿位置し ている。阔地方は㷺江立岩 倠1により圆幅調查がをされ て括り，先の地質圖及び石川 俊夫の作成した絬果を碂合す る之，地質圖住第 1 圖の如く で恋る。

この地域の地筫は礼岩沉よ れば, 堆積装類は, 融原系 中の，原生代上部乃至下部力

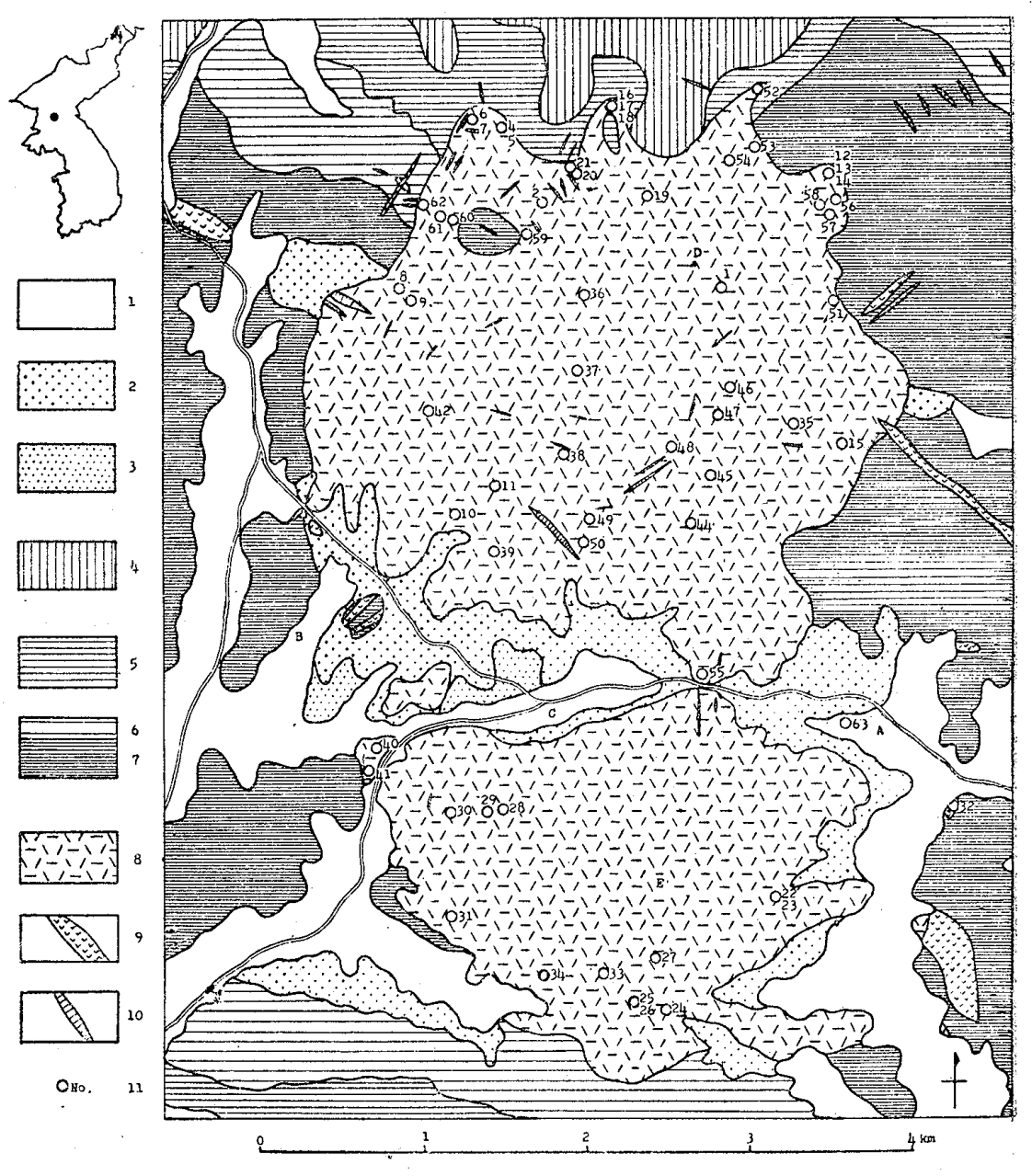

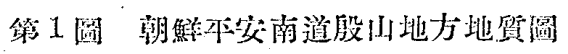

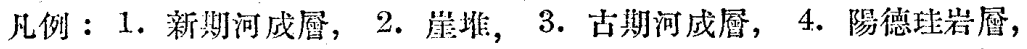

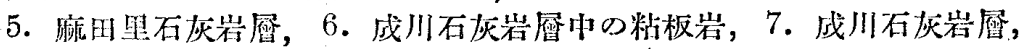

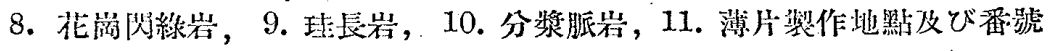
地名: A. 龍澤里, B. 明德里, C. 孤松亭, D. 崇娥近 $(684.7 \mathrm{~m})$, E. 衫山 (228.0m)

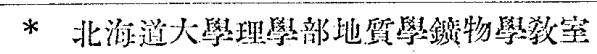

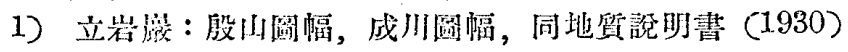

2）山口瓔雄は祥原系がゴトランド系であるらしいと述べている

仙口貴雄：所謂漣川系と之り Regional Metamorphismについて，地質雜, Vol. 57, No. 673 (1951)

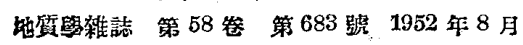




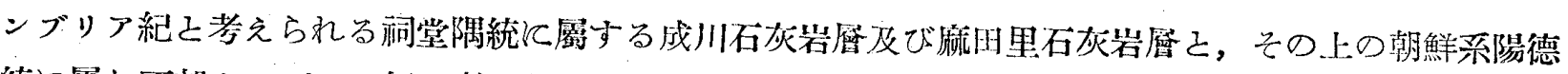

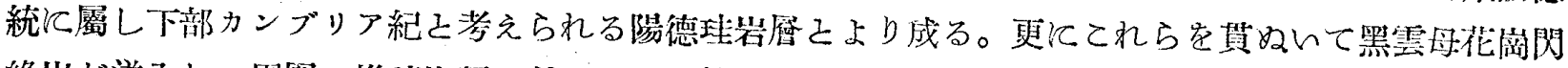

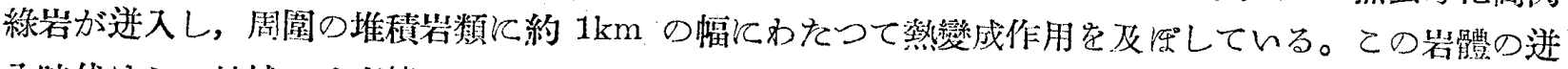

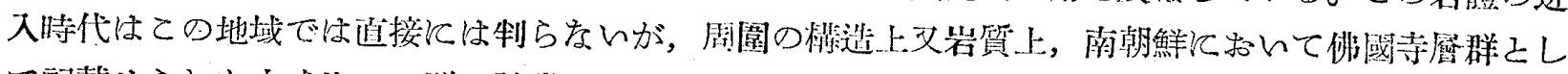

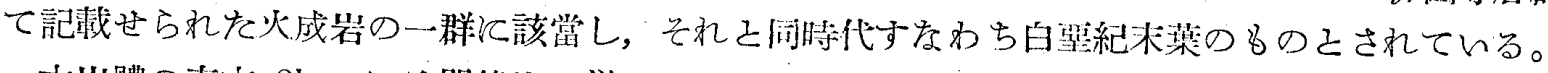

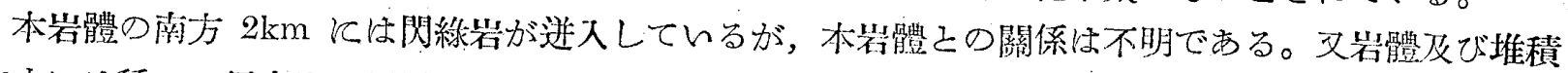
岩中には種及の優白岩・優黑岩及び理长岩が逝入しているが，でれらは化菊閃綠岩體て大體同時代の

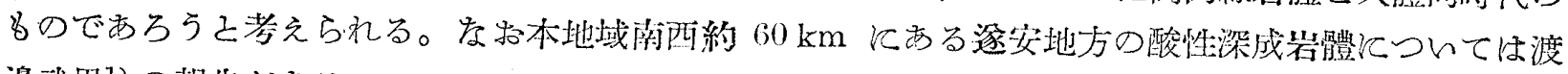
邊武男”の㘧告がある。

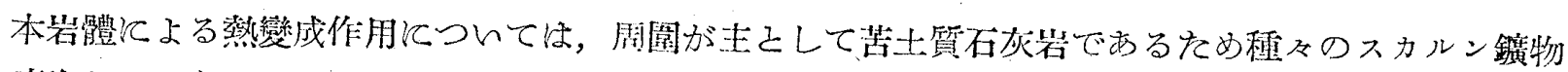

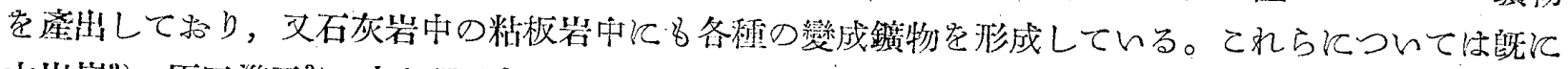

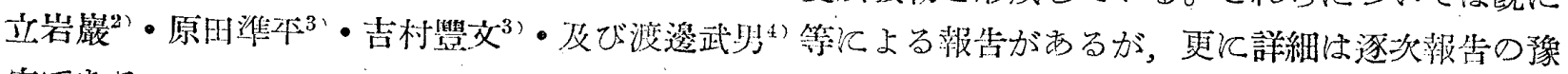
尘で流る。

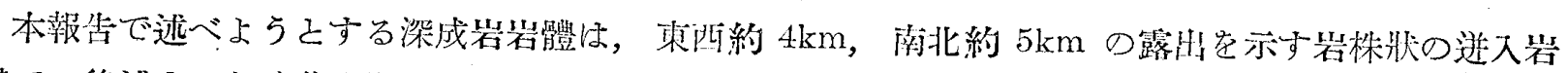

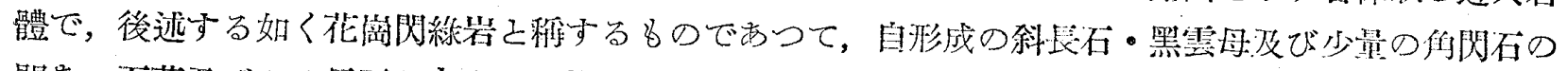

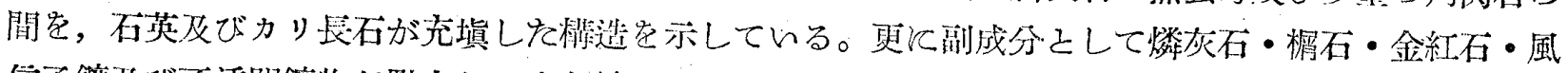

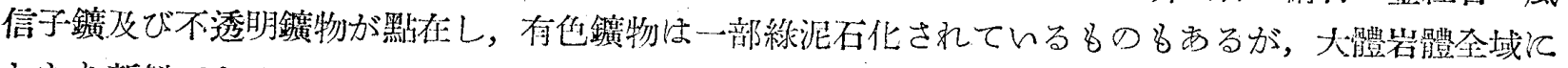
わたり新鮮である。

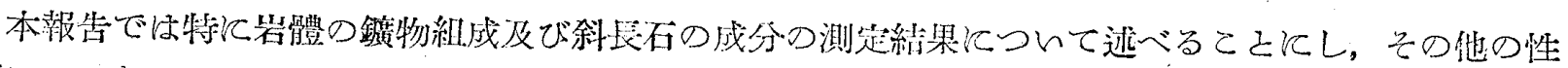

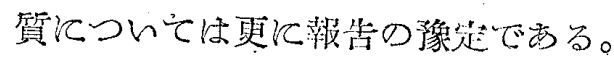

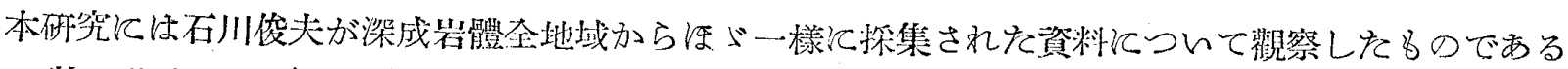

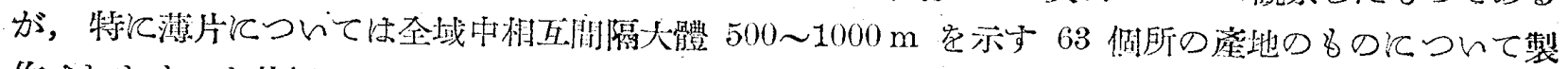

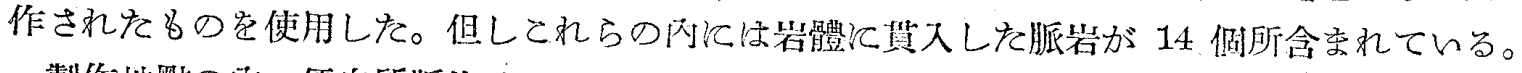

製作地點の內，優白質脈岩は 4・5・18・24・29・31・41 及び 62, 優黑質脈岩は $12 ・ 13$ 文び 51, 中性質岩は 43 及び 58 岩體外つ脈岩は 32 である。

A. 一標本內の成分變化

\section{3. 岩石の性犋}

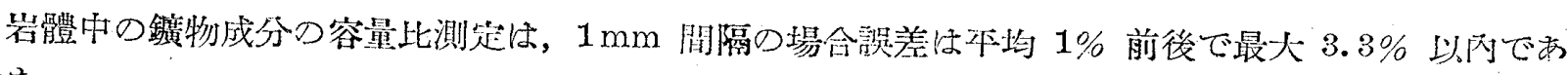
つた。

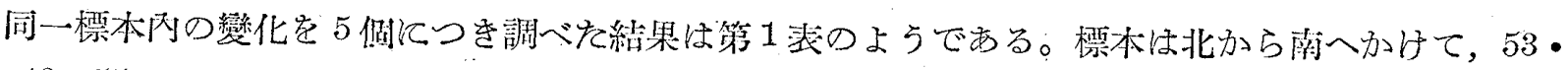

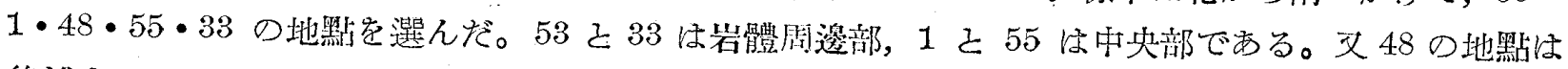

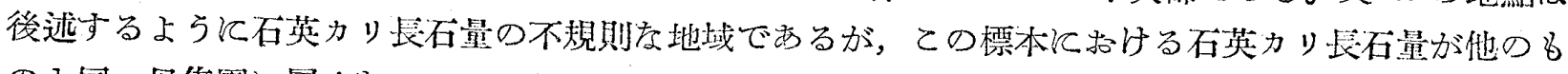

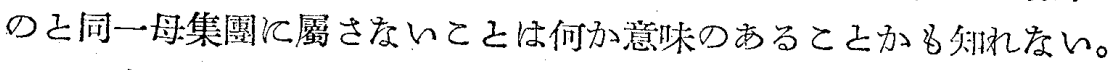

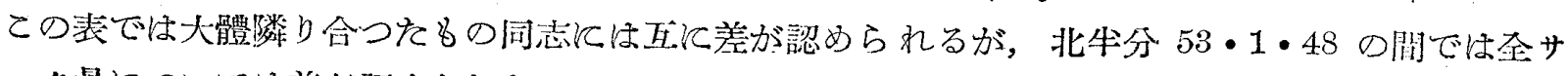
リック量につんては差が認められない。

1) Watanabe, T: Geology and Mineralization of the Suian District, Tyosen (Korea), Jour. Fac. Sci. Hokkaido Univ., Ser. IV, Vol. II, (1943)

2) 立岩淮：前出

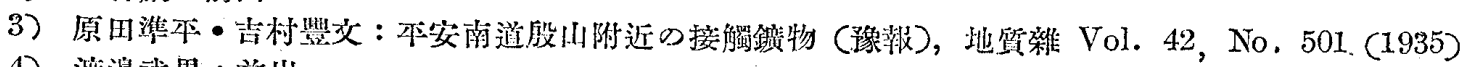

4) 渡漫武男 : 前出 
籍

表

\begin{tabular}{|c|c|c|c|c|c|c|c|c|}
\hline No. & 石筑 & カリ佥石 & 斜韭不 & 伯閃石 & 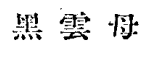 & 基 他 & 石染力リ長石琶 & 全少リック量 \\
\hline $\begin{array}{l}53-0 \\
53-1 \\
53-2 \\
53-3 \\
53-4\end{array}$ & $\begin{array}{l}23.9 \\
24.7 \\
22.7 \\
24.8 \\
24.8\end{array}$ & $\begin{array}{l}18.1 \\
22.9 \\
21.8 \\
16.7 \\
15.0\end{array}$ & $\begin{array}{l}44.1 \\
44.5 \\
45.2 \\
49.1 \\
48.5\end{array}$ & $\begin{array}{l}4.9 \\
1.8 \\
0.7 \\
1.6 \\
2.3\end{array}$ & $\begin{array}{l}8.7 \\
6.1 \\
9.3 \\
7.7 \\
9.3\end{array}$ & $\begin{array}{l}0.3 \\
0.0 \\
0.3 \\
0.1 \\
0.1\end{array}$ & $\begin{array}{l}42.0 \\
47.6 \\
44.5 \\
41.5 \\
39.8\end{array}$ & $\begin{array}{l}86.1 \\
92.1 \\
89.7 \\
90.6 \\
88.3\end{array}$ \\
\hline $\begin{array}{l}1-0 \\
1-1 \\
1-2 \\
1-3 \\
1-4\end{array}$ & $\begin{array}{l}31.6 \\
24.2 \\
29.5 \\
26.8 \\
29.3\end{array}$ & $\begin{array}{l}22.2 \\
23.1 \\
18.4 \\
16.4 \\
18.8\end{array}$ & $\begin{array}{l}39.2 \\
40.8 \\
41.3 \\
44.9 \\
39.1\end{array}$ & $\begin{array}{l}0.0 \\
0.3 \\
0.8 \\
1.0 \\
1.3\end{array}$ & $\begin{array}{r}6.5 \\
11.4 \\
9.6 \\
10.5 \\
11.4\end{array}$ & $\begin{array}{l}0.5 \\
0.2 \\
0.4 \\
0.4 \\
0.1\end{array}$ & $\begin{array}{l}53.8 \\
47.3 \\
47.9 \\
43.2 \\
48.1\end{array}$ & $\begin{array}{l}930 \\
88.1 \\
89.2 \\
88.1 \\
87.2\end{array}$ \\
\hline $\begin{array}{l}48-0 \\
48-1 \\
48-2 \\
48-3 \\
48-4\end{array}$ & $\begin{array}{l}26.9 \\
25.3 \\
32.6 \\
27.4 \\
26.3\end{array}$ & $\begin{array}{l}17.7 \\
18.6 \\
13.4 \\
18.4 \\
19.9\end{array}$ & $\begin{array}{l}42.8 \\
47.5 \\
45.5 \\
43.3 \\
42.3\end{array}$ & $\begin{array}{l}1.4 \\
1.1 \\
0.6 \\
1.7 \\
1.6\end{array}$ & $\begin{array}{r}10.5 \\
7.4 \\
7.8 \\
9.0 \\
9.2\end{array}$ & $\begin{array}{l}0.7 \\
0.1 \\
0.1 \\
0.2 \\
0.7\end{array}$ & $\begin{array}{l}44.6 \\
43.9 \\
46.0 \\
45.8 \\
46.2\end{array}$ & $\begin{array}{l}87.4 \\
91.4 \\
91.5 \\
89.1 \\
88.5\end{array}$ \\
\hline $\begin{array}{l}55-0 \\
55-1 \\
55-2 \\
55-3 \\
55-4\end{array}$ & $\begin{array}{l}25.2 \\
30.9 \\
31.6 \\
30.9 \\
26.6\end{array}$ & $\begin{array}{l}30.1 \\
24.9 \\
20.8 \\
24.3 \\
24.1\end{array}$ & $\begin{array}{l}37.9 \\
35.5 \\
40.7 \\
36.8 \\
39.5\end{array}$ & $\begin{array}{l}0.1 \\
0.4 \\
0.1 \\
0.4 \\
0.2\end{array}$ & $\begin{array}{l}5.0 \\
7.0 \\
6.5 \\
7.4 \\
9.3\end{array}$ & $\begin{array}{l}1.7 \\
1.3 \\
0.3 \\
0.2 \\
0.3\end{array}$ & $\begin{array}{l}55.3 \\
55.8 \\
52.4 \\
55.2 \\
50.7\end{array}$ & $\begin{array}{l}93.2 \\
91.3 \\
93.1 \\
92.0 \\
90.2\end{array}$ \\
\hline $\begin{array}{l}33-0 \\
33-1 \\
33-2 \\
33--3 \\
33-4\end{array}$ & $\begin{array}{l}22.9 \\
27.1 \\
21.0 \\
23.6 \\
22.6\end{array}$ & $\begin{array}{l}17.7 \\
12.6 \\
15.0 \\
14.4 \\
14.5\end{array}$ & $\begin{array}{l}44.8 \\
47.2 \\
48.9 \\
47.4 \\
50.9\end{array}$ & $\begin{array}{l}3.5 \\
4.1 \\
7.3 \\
5.7 \\
3.6\end{array}$ & $\begin{array}{r}10.7 \\
8.8 \\
7.8 \\
8.7 \\
8.0\end{array}$ & $\begin{array}{l}0.4 \\
0.2 \\
0.0 \\
0.2 \\
0.4\end{array}$ & $\begin{array}{l}40.6 \\
39.7 \\
36.0 \\
38.0 \\
37.1\end{array}$ & $\begin{array}{l}85.4 \\
86.9 \\
84.9 \\
85.4 \\
88.0\end{array}$ \\
\hline
\end{tabular}

1) 數值は容量\%を表わす

3）、全サリック量二石资十カリ長石十科脣石

2）石筷刃り長石最二石笑十カリ長石

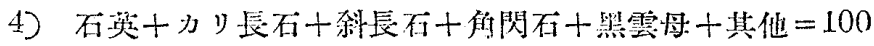

B. 署石中の石英・カリ长石及び斜長石の量

殷山の酸性深成岩體中の標本につんて，造岩鑸物の容量 比を Integrationstisch により測是したが，各々の教值は 省略する。てれらのうちで性斜長石・石英及びカリ長石が

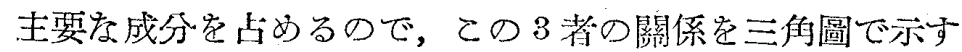

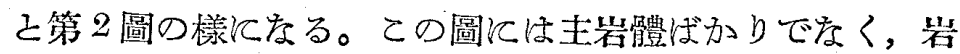

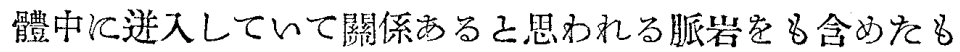
ので，乙れ等隹同一倾向を持つているが，32 地點の如き 岩體から離れた脈岩には全く性質の罢をつをるのがある。 北米東部 New-England 地方の花耑岩體につんて CHAYES ${ }^{1)}$ が同樣の測趋を行つたもの之比校する之，殷山の\& のは此較的ちらばつている。しかし筆者名がさき報告し た北上山地高田町附近の花崗閃綠岩體飞比べる之，ての地 域の岩體のもの〉方がよく集まつている。てのて之は以上 3 個所の岩體の成分の一樣さ關係があるのであろう。

岩體定構成する各所の岩石につんて, 上記 3 鏗物の和・ 比率及び有色鐄物の種類等を考察する之，岩體中には部分

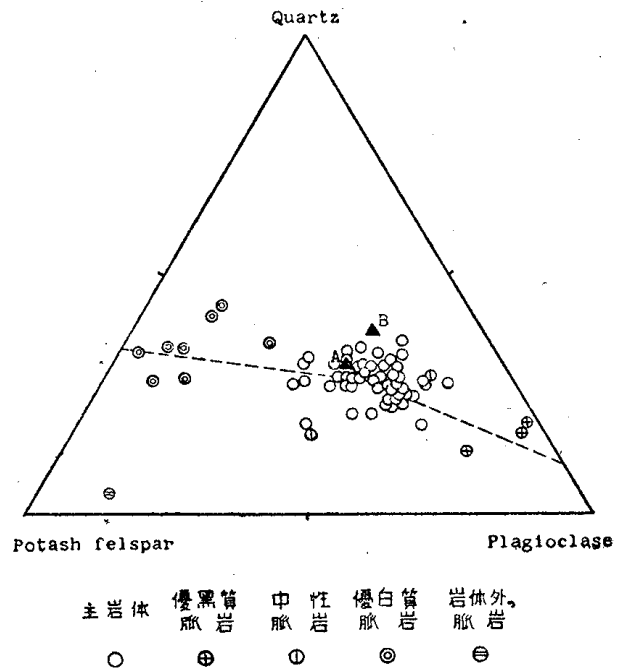

第 2 圖 殷山岩體のサリック鐄物異量比 上部. 石资, 左. カリ長石, 右. 斜長石, 哭

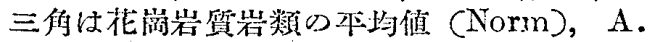
歐米型, B. 日本型, 點線は偍白質脈和・主岩

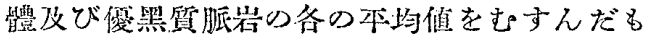

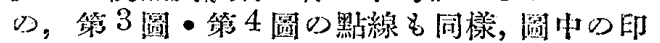
は第 2 國・第 4 圆・第 6 圖其通である

1) ChraYes, F.: Composition of some New England granites, Trans. New York Acad. Sci. Ser. 2, Vol. 12, No. 5, (1950)

2) 鈴木淑夫：北上山地南部高田旷附近の花蔄閃綠岩の棈造について，地質雜，Vol. 58，No. 676 (1952) 
的には adamellite, normal granite と云らべき岩種も認められるが，岩體全體としては granodiorite 之科するのが最も適當で西らう。

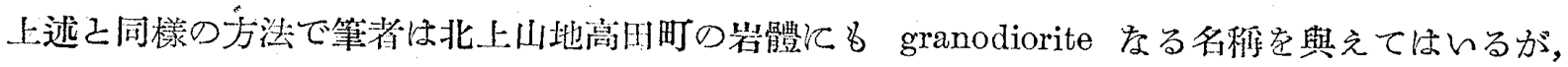

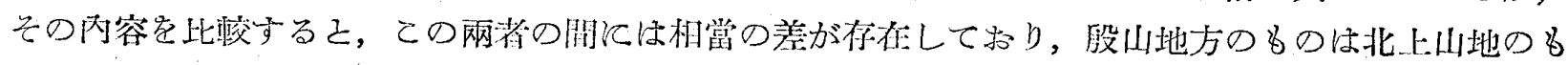

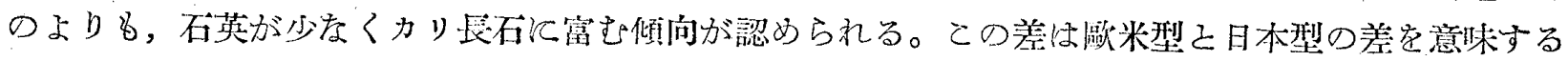

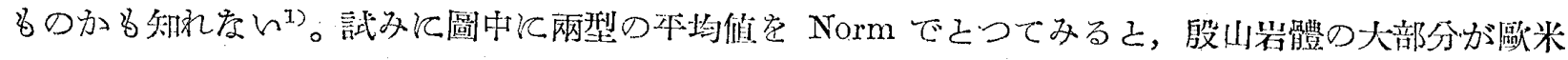
型の點に近い性質を示しているこ己は注目に佔するこよでする。

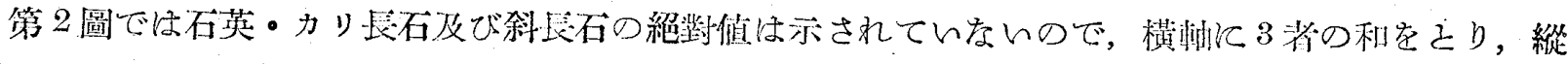

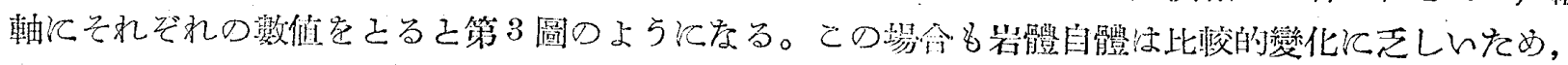

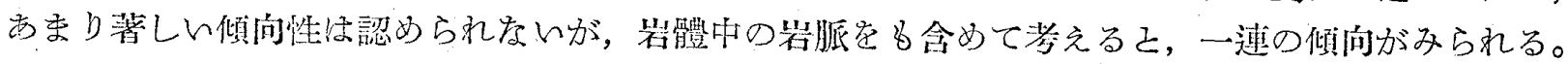

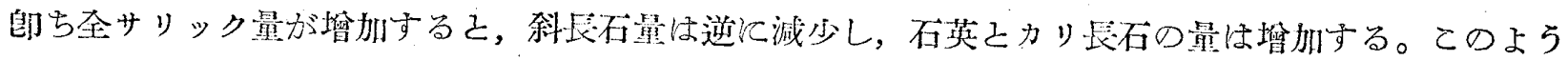

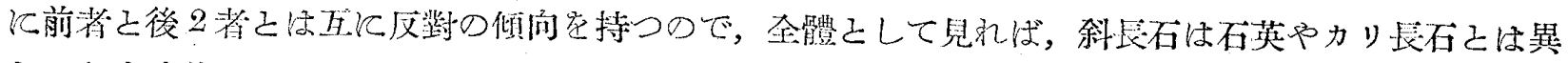

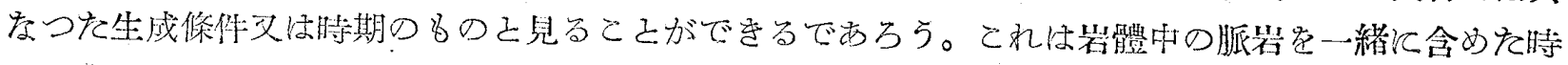

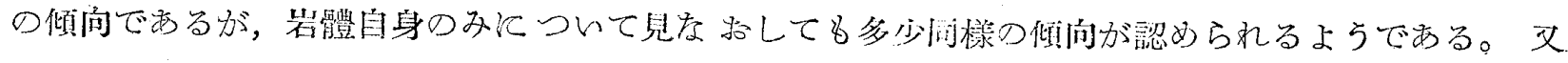

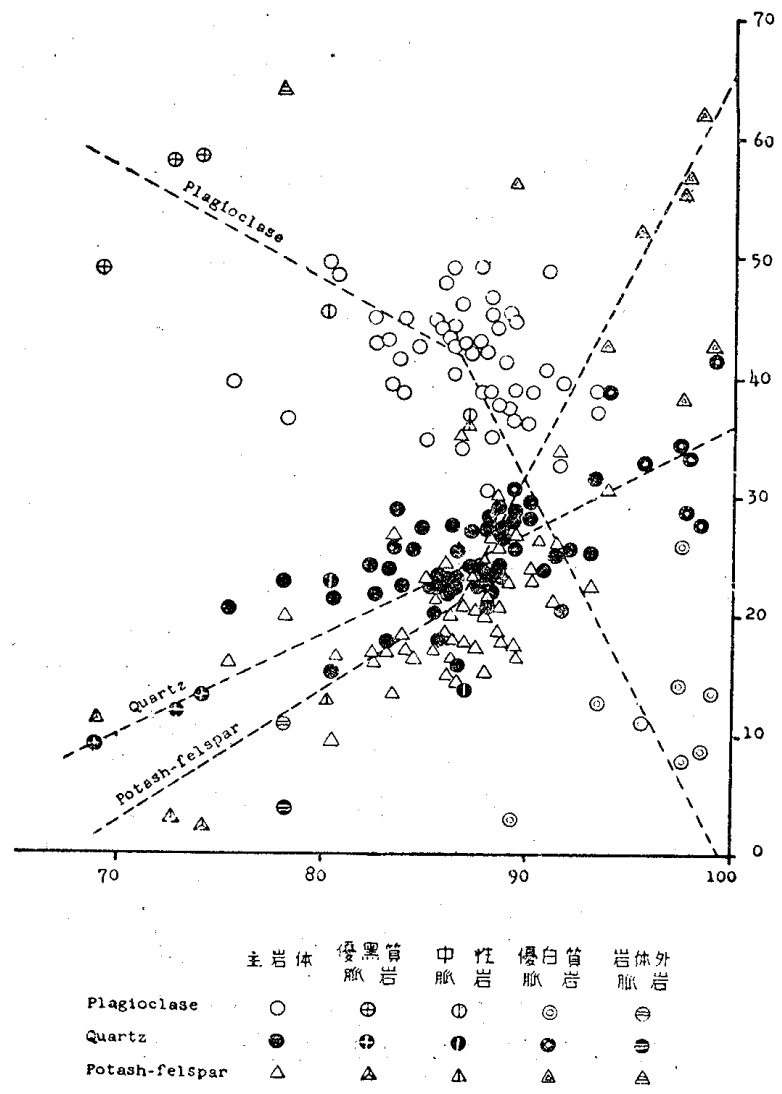

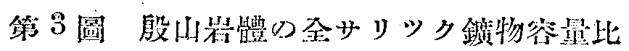

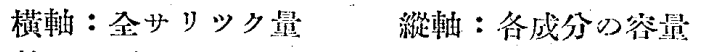
数值は\%を裴わす

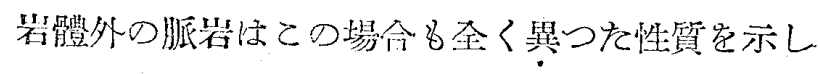
ている。

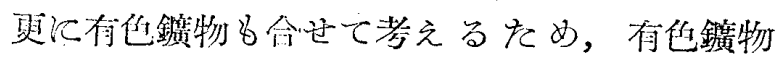

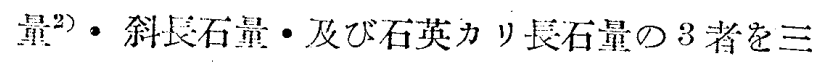

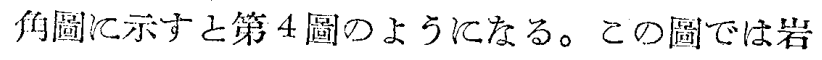

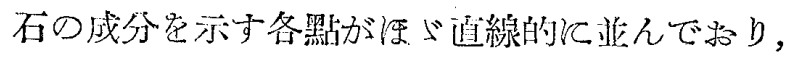

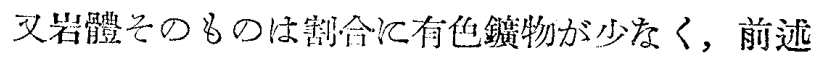
の北上山地の\&のよりは珄酸量の多いて之が揫想

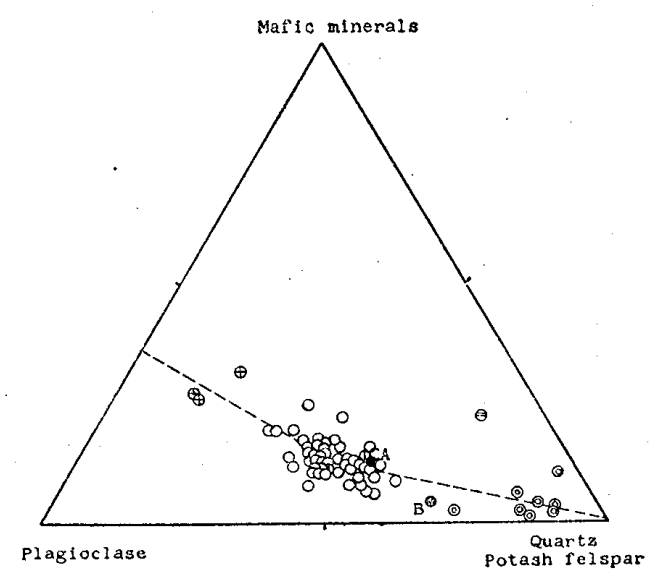

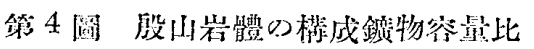

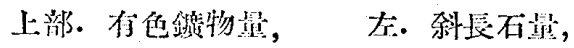

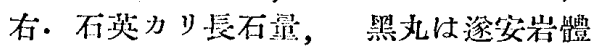
めめ, A. 遂安花南岩 (周遥部),

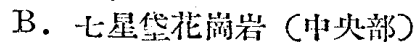

1) Suzuki, J. and Namoro, T.: The Chemical Composition of the Granitic Rocks of Japan, Jour. Fac. Sci. Hokkaido Univ., Ser. 1V, Vol. III, No. 1 (1933)

2) 有色鎔物量 $=$ 黑雲时十们閃石十其他 
される。

脈岩を除いを岩體の主婯部分は近似した值を示しているが，全體の倾向は北上山地のそれとは相當 飞異なつている。な和本岩體の南東約 $60 \mathrm{~km}$ の逐安地方の岩體につんて渡邊武男の測定した量比を

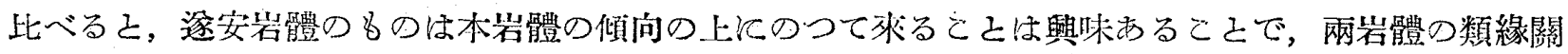
係思吅せるものがある。

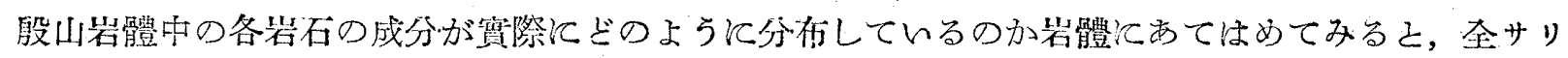

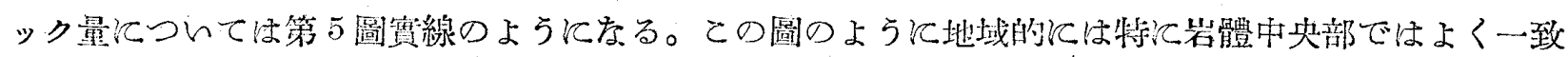

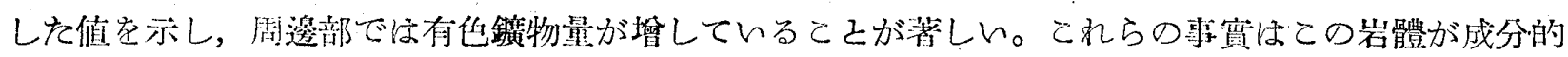

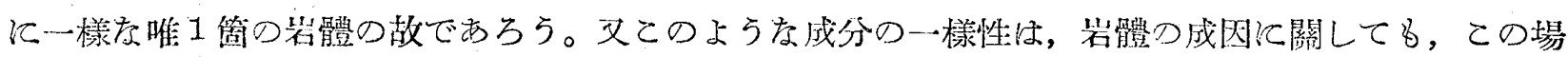

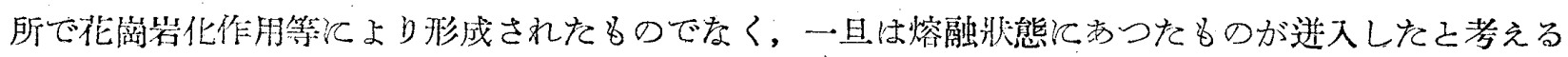

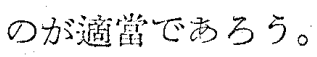

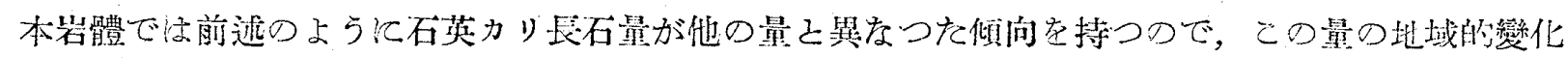

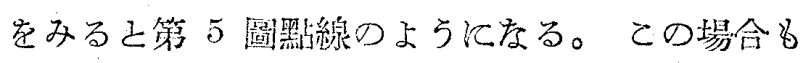

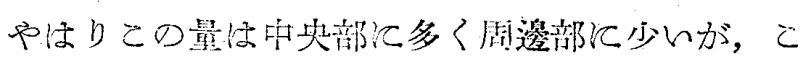

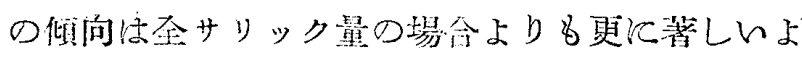
らである。

要する江ての主岩體活，部分的江多少の變化は

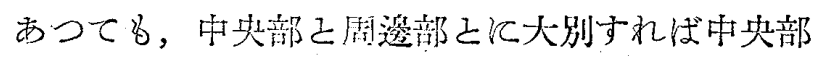
が優白質で方るここが認められる。前述の遂安岩 骼てつんても, 類似のて之が述べられているて之 は注意すべきで范る。唯ての埸合は 2 簓の異つた もの上されているが，倾向亡しては同樣江考える ここができるであろう。北上山地の例では，ての

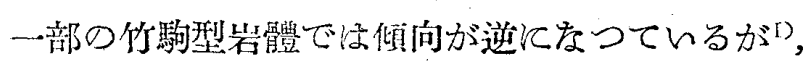
このととはこの岩體內部の石英カり長石量が特的

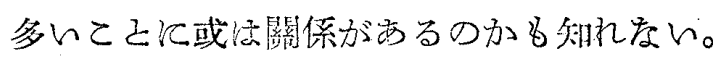

C. 岩石中の有出鍰物量

岩體中の有色鐄物は土之して黑雲母であるが，

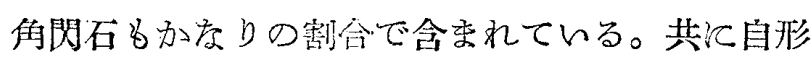

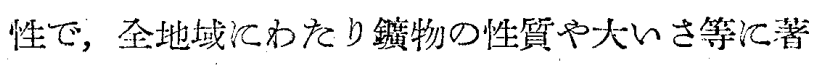
しい變化はみられ少い。

この兩者の容量比を较べる之第 6 圖のよう亿を る。岩體全體己しては有出鍰物の少い閒は黑雲母

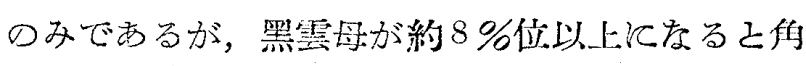

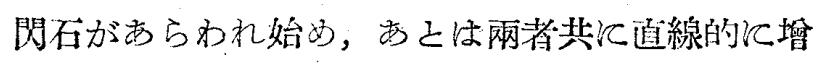
加する攸问が認められる。西る程度黑雲母多く

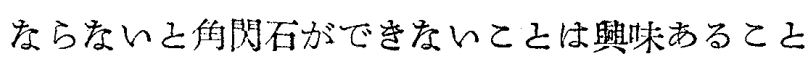
である。

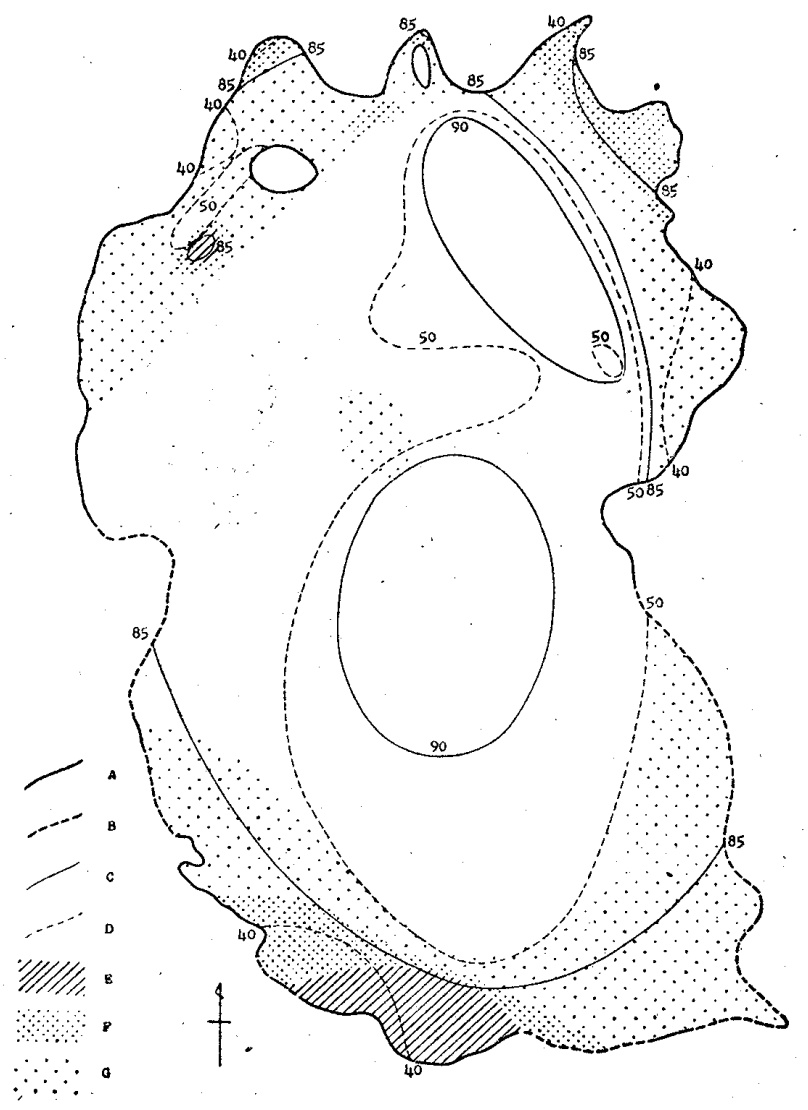

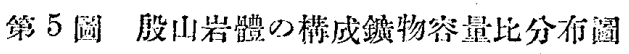

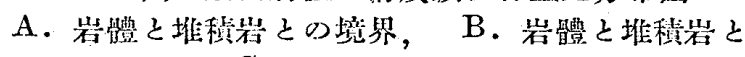
心推定境界， C. 全サリック量等做線(石英十力 》長石十斜長石)，D. 石资カリ長石星等值線(石

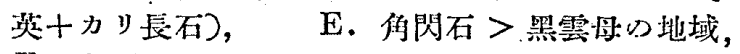
F. 侮閃石 : 哭雲时=5:5 4:6 の地域, G. 觕閃

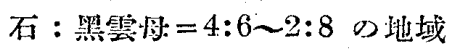
圆中心数值は\%を示す

\section{1) 鈴木淑夫：前出}




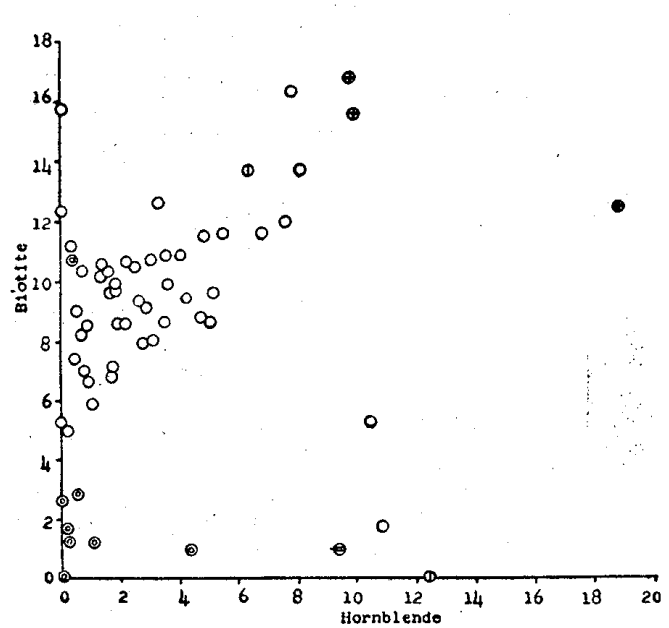

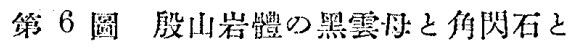
o.

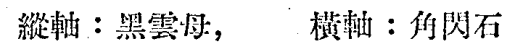
教值は\%を裴わす

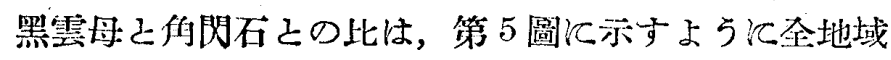
で大體類似しているが，岩體つ南端部に恃特化閃石に

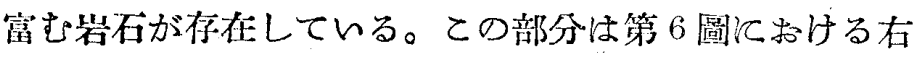
下の點で，全體の傾向とはかなり離れており，或はての 地域泟同化作用のようを影暗が西つたのか多然れない。

D. 岩體內の鏔物量比の差異

段山岩體は全體を通じて比较的一樣な成分であるが， 唯中央部が䦌邊部よりも優白質で，特江石英カリ長石量 に富さこ之は毁にのべた通りであるが，部分的には特異

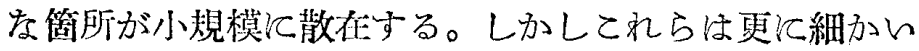
變化で全體つ倾向は支配しないようである。

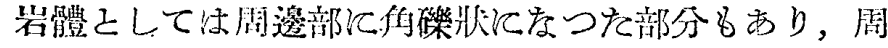

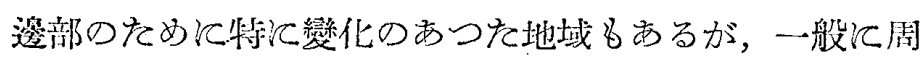

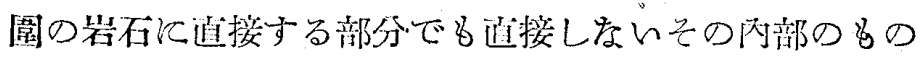

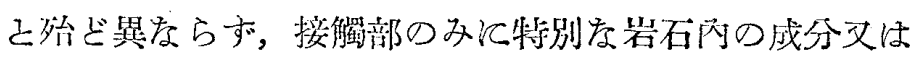

精造上の變化がをかつたてとを示している。

\section{4. 岩石中の斜長石成分}

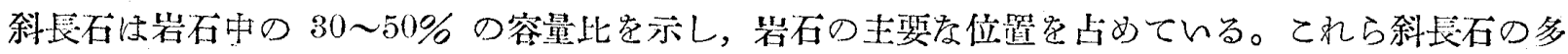

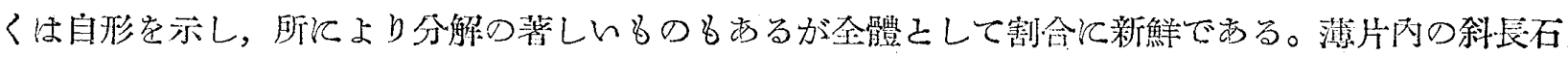

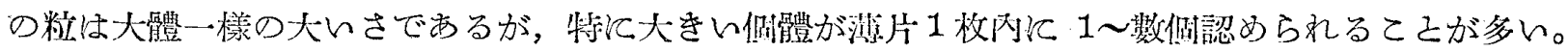

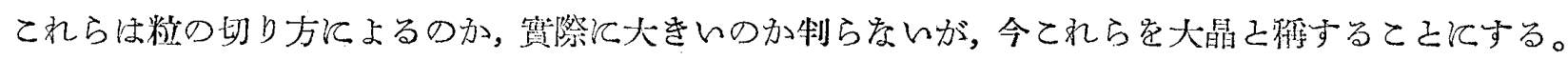

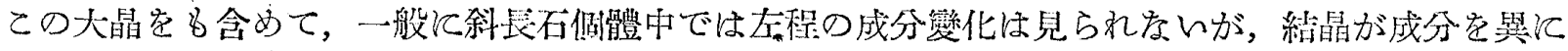
する薄い斜長石の膜で包まれているものが少くない。

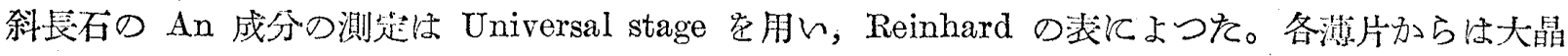

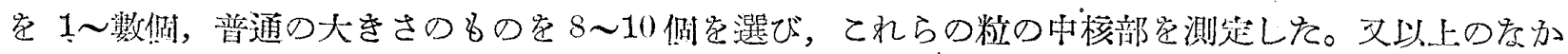

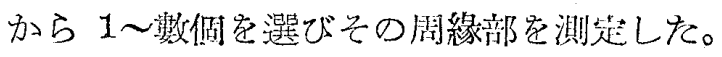

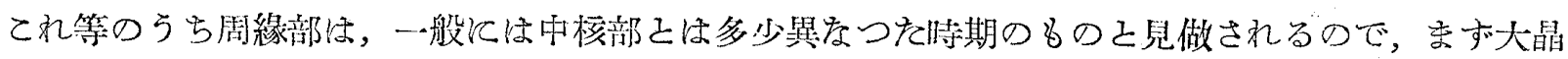

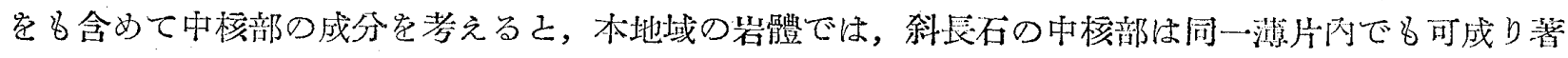
しい成分變化を示しており，大體 An 25 45\% 程度のひらきが認められる。一方岩體全體安通してて

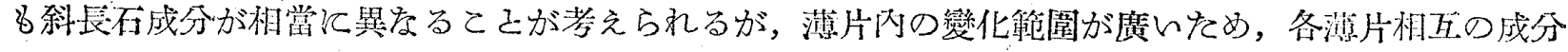

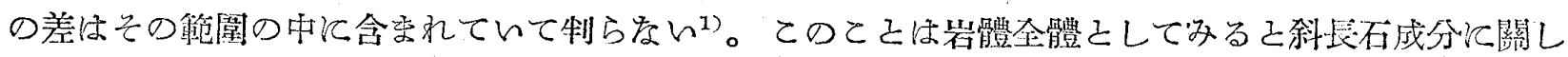

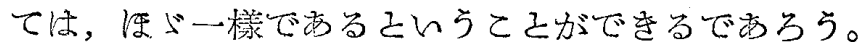

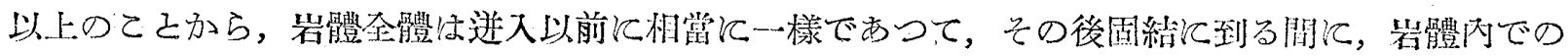

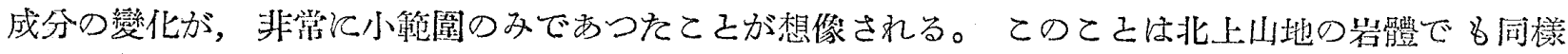

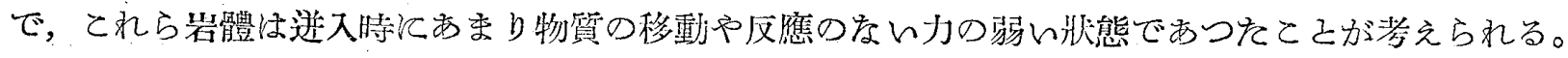

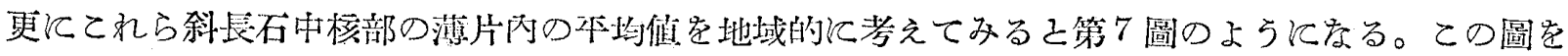

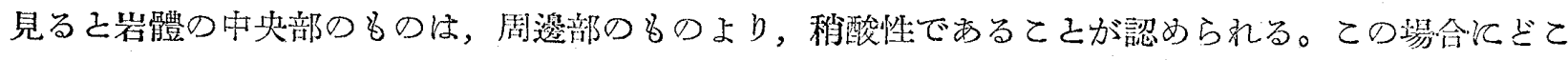

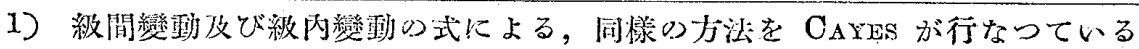

Chaysi, F.: Compositon of the granites of Westerly and Bradford, Rhode Island, Amer. Jour.

Sci. Vol. 248, June, (1950) 


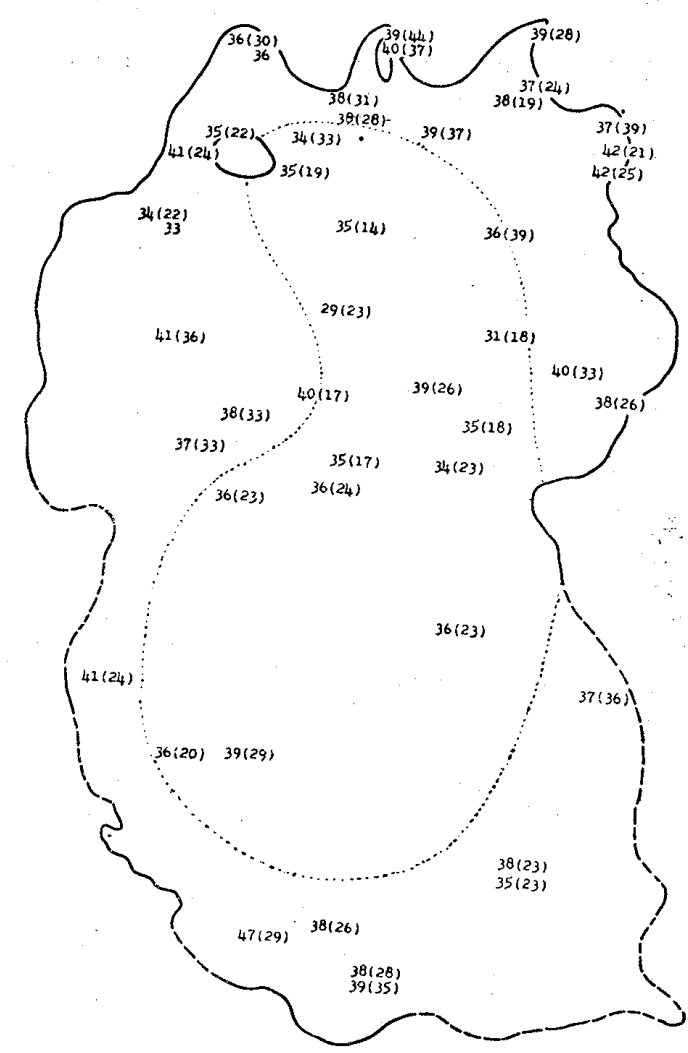

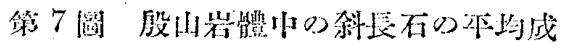
分心分倠泪

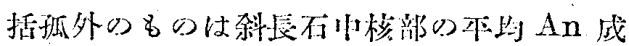

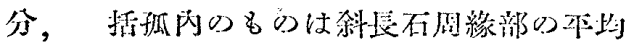

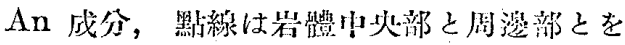
分けるため假定した線

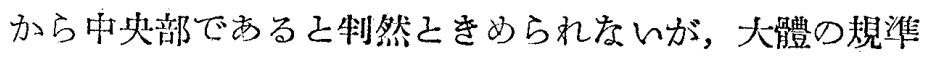

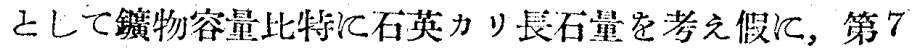

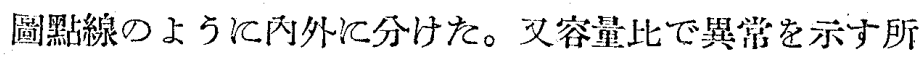
は除外して考えた。

てのよ5亿分壮を埸合，中央部は平均 An $35 \%$ 風邊 部は本均 $39 \%$ 之秀り，䦌邊部が An 成分伅富んでいる

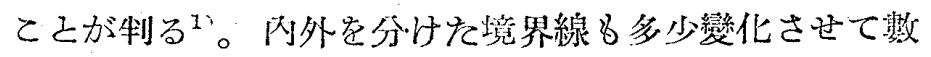
回行つたが類似の結果它得たので，引き方にはよらをい もの上琹わ秃る。

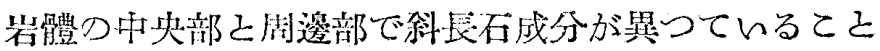
は侧々の潐片队の成分變化の大きい乙二から，迸入時以 後飞分れをのでは存くて，科圭石の晶特以前に熔融體 白體が異存つた成分学有していたものであらら。恐らく

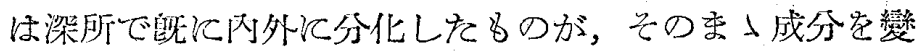

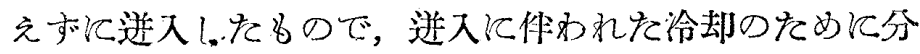

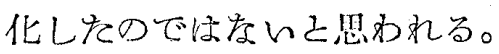

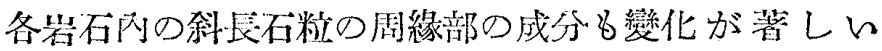

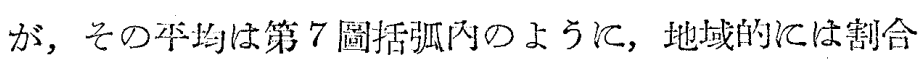

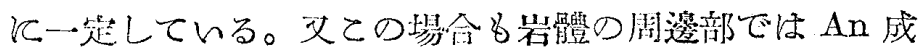

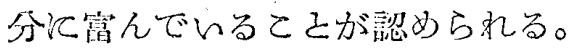

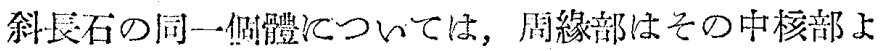

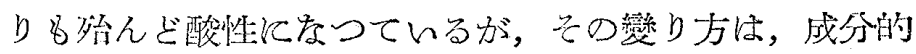

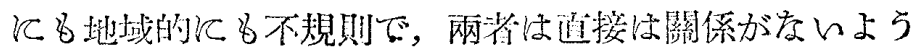
である。

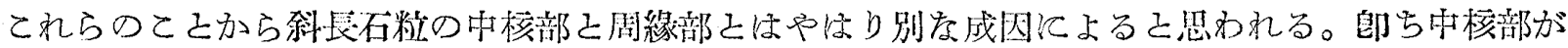

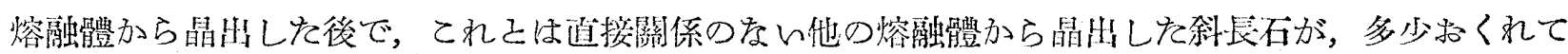

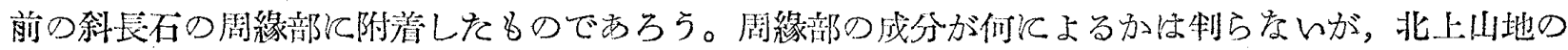

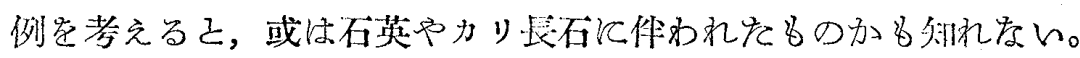

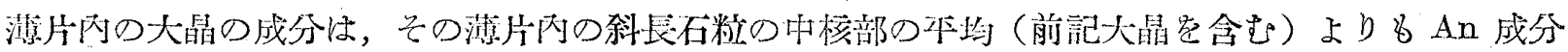

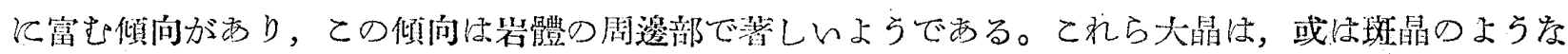

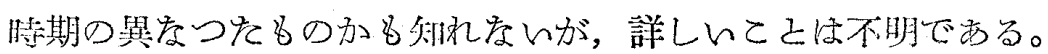

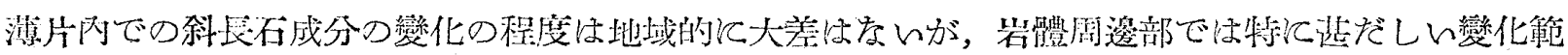

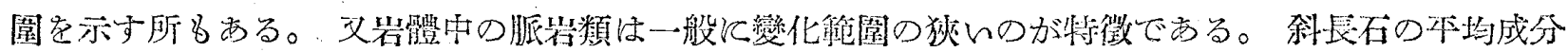

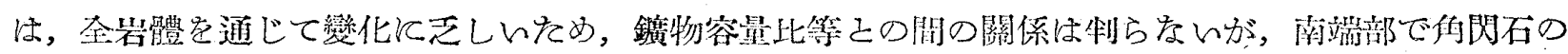

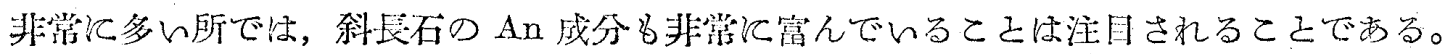

\section{5. 綜括}

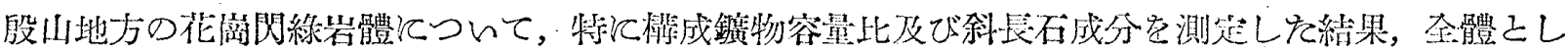

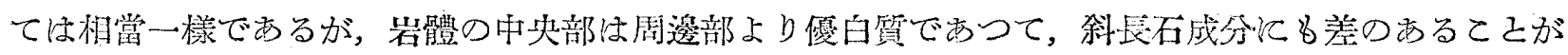

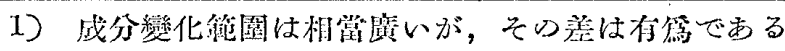




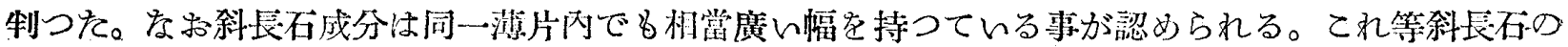
性質，分布奘態等上り推して，䂟體內の部分的成分變化はすで地下深所飞於て行われており，その まっ迸入固結したるのの樣と思われる。

\section{On the Structure of the Granodiorite Mass in the Inzan District in Northern Korea}

(Abstract)

\section{Yoshio SUZUKI}

There is a granodiorite mass occurring as a small rounded stock, $5 \mathrm{~km}$. in maximum diameter, in the Shogen and Chosen systems in the Inzan district, northern Korea. The subject matters of this paper are the results of laboratory investigation of the rock samples which were collected by Prof. Toshio Isminawa from 63 localities in this granodiorite mass during 1941. A careful examination of the volumetric relations of the essential constituent minerals, and the composition of the plagioclase, of these samples has led the writer to the conclusions that the mass shows nearly homogeneous nature though the marginal zone of the mass is a little basic compared with the central part of it. The details on the geology and the interesting metamorphic rocks around the igneous mass will be described on some future occasions.

，抄 錄

\section{Kurt Fiege: The Zone, Base of Biostratigraphy}

(Bull. Amer. Assoc. Pet. Geol., Vol. 35, No. 12, pp. 2582 2596, 1951)

著者はこの諭文のゆで、、ろいろの人が便つてきた

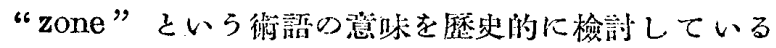
が，三三心顀例を第げて fauna による zone を geoー

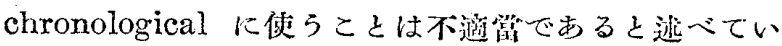
る.さらに, geochronologyに招いて用いられている

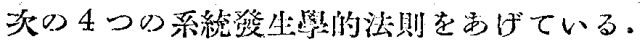

(1) neomorphosis 抽上び palingensis. (2) 生物

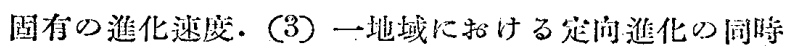

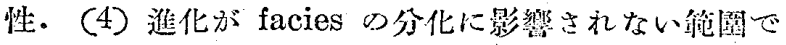
の環境加ら獨立性.この法則に基いて, “Zone is a life-time of a link (a species) of a phylum, whose progenitor and descendant are known" $と し て い$ る.

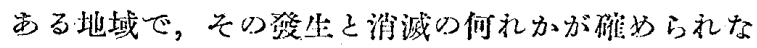
い種の生存期間によつて规定された“zone”を“par一 tial zone”をよど，またいずれも磪的られない種によ るものを horizon とよんでいる。 FIEGE の数えによれ げ horizon-fossil 扣よび fauna は共に facies fossiI で，facies が同暗确を切らないばあいには，“faunal zone”ではなく “faunal horizon”をよばれねばな らない。

この上らにしてそれぞ礼别䛧にきめられた2つめ生 物㪊 (stock) によつてきめられた zone の順序を投影 しあらことによって “subzone”が得られる。したが

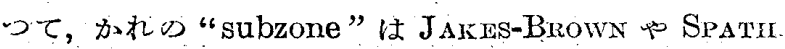
つ使つている恚味とは罢なる。

㵔者は，最後に多くめ矛盾は zone, partial zone, horizon といら言萖の使い方の混亂から生ずるもの で, time-scale の基隻としての zone の意味を統一し たいと梆へている。

(大森昌街) 